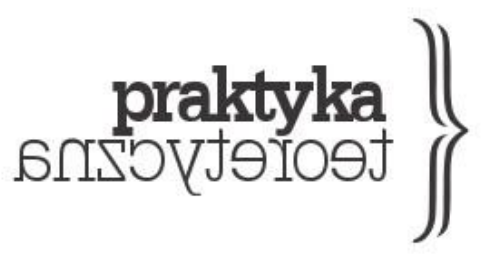

\title{
WIELOKRYTERIALNA OCENA PROJEKTÓW BEZWARUNKOWEGO DOCHODU PODSTAWOWEGO I GWARANTOWANEGO ZATRUDNIENIA
}

\author{
MARIUSZ BARANOWSKI, BARTOSZ MIKA
}

\begin{abstract}
Abstrakt: Autorzy stawiają sobie za cel porównanie dwóch szeroko dyskutowanych współcześnie propozycji reformy rozwiniętego państwa dobrobytu: bezwarunkowego dochodu podstawowego oraz programu gwarancji zatrudnienia. Propozycje te zostaną rozpatrzone z uwzględnieniem: kosztów i warunków finansowania, oddziaływania na istniejąca siatkę zabezpieczeń socjalnych, wpływu na nierówności dochodowe, efektu emancypacyjnego oraz politycznych możliwości realizacji. We wnioskach wyróżnionych w podsumowaniu autorzy biora pod uwagę odmienne potrzeby krajów centrum i peryferii, a także sugeruja, że niewielkie doświadczenie empiryczne związane $z$ dochodem podstawowym, jego potencjalnie niekorzystny wpływ makroekonomiczny oraz niepewny efekt emancypacyjny czynią bardziej przekonująca propozycje gwarancji zatrudnienia.
\end{abstract}

Słowa kluczowe: państwo dobrobytu, pełne zatrudnienie, ubóstwo, wykluczenie społeczne, transfery gotówkowe. 


\section{Wprowadzenie}

Ideę bezwarunkowego dochodu podstawowego (dalej także BDP lub dochód podstawowy) należy bezdyskusyjnie zaliczyć do postulatów wyraźnie słyszalnych w głównym nurcie debaty publicznej. Szwajcarzy w 2016 roku przeprowadzili referendum nad wprowadzeniem tego rozwiązania, w Indiach prowadzono liczne eksperymenty wzorowane na pomyśle BDP, Finowie w styczniu bieżącego roku rozpoczęli własne testy reformy polityki społecznej bliskie tej idei, choć niespełniające wszystkich wytycznych stawianych BDP (zob. Van Parijs 2009). Także w bieżących sporach politycznych dostrzegalna jest obecność postulatu wprowadzenia dochodu podstawowego - przykładem niech będą wypowiedzi Benoîta Hamona, kandydata francuskich socjalistów w tegorocznych wyborach prezydenckich. Proponowal on początkowo 750 euro dochodu podstawowego dla każdego obywatela powyżej 18 roku życia, opodatkowanie maszyn oraz skrócenie czasu pracy do 32 godzin tygodniowo. Do zwolenników BDP - w różnych jego postaciach - zaliczają się również Guy Standing, były główny ekspert Międzynarodowej Organizacji Pracy, Joseph E. Stiglitz, laureat Nagrody Banku Szwecji im. Alfreda Nobla, czy Janis Warufakis, były grecki minister finansów. Szerokie i różnorodne ideowo poparcie dla idei BDP prowadzi do poważnej trudności związanej z tą propozycją - mianowicie wskazuje na jej wieloznaczność. Poszczególni obrońcy dochodu podstawowego prezentują tę koncepcję odmiennie, różniąc się nie tylko w szczegółach, ale czasem w bardzo elementarnych kwestiach (np. dotyczących sposobu finansowania BDP, spodziewanych efektów czy zakładanego kształtu i zakresu zmiany instytucji polityki społecznej).

Mniej kontrowersyjna $z$ tego punktu widzenia jest - często prezentowana jako konkurencyjna (zob. np. Harvey 2012) - propozycja pracy gwarantowanej lub gwarancji zatrudnienia (dalej GZ). Idea ta, szczególnie bliska intelektualnym spadkobiercom Johna Maynarda Keynesa, takim jak Joan Robinson, L. Randall Wray, Matthew Forstater czy Philip Harvey, nie jest współcześnie tak szeroko dyskutowana, ale wydaje się bardziej spójna i pomimo różnic w poszczególnych jej propozycjach sprowadza się do mechanizmu państwa jako pracodawcy ostatniej szansy.

W niniejszym opracowaniu podejmiemy próbę porównania postulatów bezwarunkowego dochodu podstawowego oraz gwarancji zatrudnienia. Zadanie to jest o tyle złożone, że w obydwu przypadkach możemy opierać się jedynie na fragmentarycznych lub czasowo ograniczonych eksperymentach i programach świadczeń. Ponadto, jak zostało zauważone, w ramach obydwu propozycji, a raczej ich poszczególnych wariantów, występuja doniosłe różnice. Dotyczą one nie tylko spraw czysto technicznych czy instrumentalnych, ale również kwestii o charakterze zasadniczym. Dlatego już na wstępie zaznaczamy, że obydwie propozycje będą traktowane przez nas jako reformy strukturalne współczesnego, rozwiniętego welfare state, których celem jest zapewnienie możliwie szerokiego dobrobytu 
materialnego oraz dobrostanu psychicznego. Pozostawiamy zatem poza obszarem naszych zainteresowań szeroko rozumiane kwestie ustrojowe lub - odwołując się do słownika marksistowskiego - formacyjne. Nie będziemy podejmować pytań o to, która z propozycji jest bardziej antykapitalistyczna i która stwarza większe szanse na przejście do komunizmu (na temat BDP w tym kontekście zob. Wright 2005). Implikuje to również odrzucenie wszelkich argumentów odnoszących się do „zniesienia konieczności pracy”. Przyjmujemy, że obydwie propozycje - same w sobie - nie uwolnia społeczeństwa od potrzeby pracy zarobkowej. Koncepcja gwarancji zatrudnienia wyraża to niejako expressis verbis, natomiast BDP przyjmuje tę konieczność implicite ${ }^{1}$.

Nie zamierzamy również polemizować z obiegowymi opiniami, których sednem jest rzekomy „deprawujący” charakter bezpośrednich transferów pieniężnych. Chcemy skupić się na kilku podstawowych z punktu widzenia reformy współczesnego kapitalistycznego państwa opiekuńczego kwestiach²: 1/ makroekonomicznym oddziaływaniu obydwu reform, 2/ ich wpływie na istniejąca siatkę zabezpieczeń społecznych, 3/ oddziaływaniu na skalę społecznych nierówności, z jednej strony rozumianych czysto ilościowo (jako nierówności dochodowe), z drugiej bardziej relacyjnie (jako podziały klasowe), 4/ oddziaływaniu na politykę emancypacyjna, w tym również na potencjale dekomodyfikacyjnym omawianych propozycji, 5/ politycznych możliwościach wprowadzenia tytułowych programów. Oprócz tego w sytuacji rosnących nierówności, zarówno w skali narodowej poszczególnych krajów, jak i globalnej (por. Therborn 2015; Piketty 2015a), nieodzownym wydaje się podkreślenie do czego wrócimy w podsumowaniu - różnicy w możliwych formach oddziaływania obydwu propozycji w centrum i na peryferiach.

Thomas Piketty (2015a, 35) już we wprowadzeniu do swojego monumentalnego dzieła Kapitat w XXI wieku stwierdza, że „historia podziału bogactw jest zawsze historia głęboko polityczną", a sam kształt i rozmiar nierówności dochodowych i majątkowych jest wynikiem określonego podziału sił politycznych (lub mówiąc inaczej - klasowych). Podobny pogląd znajdziemy w znanym eseju Michała Kaleckiego (1979 [1943]) dotyczącym politycznych aspektów pełnego zatrudnienia, w którym autor broni tezy, że brak owego pełnego zatrudnienia jest jedynie wynikiem określonego układu sił społecznych. Uznając zasadność takich stwierdzeń, w dalszej części opracowania pominiemy częściowo kwestię „możliwości” (chyba że politycznych), a skupimy się na konsekwencjach obydwu tytułowych propozycji.

\footnotetext{
${ }^{1}$ Przykładowo Guy Standing (2013) odróżnia prawo do pracy od gwarancji zatrudnienia, krytykując drugą z tych propozycji i broniąc pierwszej z nich. Ponieważ jednak BDP jest transferem gotówkowym opartym na idei redystrybucji, musi zakładać generowanie nowej wartości w procesach pracy, zatem wprowadzenie dochodu podstawowego nie znosi społecznej „konieczności” pracy zarobkowej, a jedynie zmniejsza presję podjęcia pracy ciażącą na indywidualnych członkach społeczeństwa. Społeczeństwo jako całość wciąż musi pracować w warunkach kapitalizmu, generując nadwyżki, aby mieć co redystrybuować.

${ }^{2}$ Choć już ograniczenie negatywnych efektów oddziaływania kapitalizmu, wynikających z uspołecznienia kosztów i prywatyzacji zysków, znajdzie się w polu naszego zainteresowania.
} 


\section{Makroekonomiczne oddziaływanie BDP i GZ}

\subsection{Koszty}

Zdaniem Phillipa Harveya (2007) omawiane w prezentowanym opracowaniu programy sa postrzegane jako rozwiązania bardzo kosztowne. Gwarantowane zatrudnienie jest w zamyśle jego zwolenników odpowiedzią na moralną - obecną w Deklaracji Praw Człowieka - potrzebę zagwarantowania wszystkim obywatelom godziwego zatrudnienia (Harvey 2012). W kategoriach praktycznych jest zaś odpowiedzą na zmiany współczesnych rynków siły roboczej, na których od lat siedemdziesiątych obserwuje się stałe, relatywnie wysokie wskaźniki bezrobocia. Z drugiej strony, bezwarunkowy dochód podstawowy opiera się na pomyśle wypłaty wszystkim obywatelom i/lub rezydentom kwoty pozwalającej na godne życie (w kategoriach formalnych chodzi o minimum socjalne lub minimum egzystencji), co można uznać za największy program od czasu wprowadzenia państwa dobrobytu. Oczywistym jest też, że każdy z tych programów wymaga gigantycznych nakładów.

W dyskursie prasowym dotyczącym BDP najczęściej podaje się wielkości będące prostą sumą wypłat określonej kwoty dla wszystkich beneficjentów (nie są to więc realne koszty budżetowe, które powinny uwzględniać zarówno oszczędności na innych programach, jak i planowane reformy podatkowe). W wywiadzie z 2011 roku Ryszard Szarfenberg szacował tą metoda koszty dochodu podstawowego dla wszystkich obywateli polskich na około 450 mld PLN (Szarfenberg 2011, zob. też Szlinder 2017). Trzy lata później Marcin Jendrzejczak (2014) podawał kwotę 360 mld PLN (uwzględniając tylko dorosłych mieszkańców Polski), a w maju bieżącego roku Piotr Szumlewicz (2017) obliczył tak rozumiany koszt programu BDP na 460 mld PLN33. Bardziej precyzyjne dane, uwzględniające realne koszty budżetowe, zawierają znacznie niższe kwoty. Niedawno Karl Widerquist (2017) zaproponowal szacunek kosztów BDP dla Stanów Zjednoczonych uwzględniający jedynie wydatki dla beneficjentów netto. Jego obliczenia wskazują na roczny nakład $539^{4}$ mld USD (co stanowi 16\% kosztu liczonego metodą sumowania wydatków) w przypadku bezwarunkowego dochodu finansowanego na zasadzie zbliżonej

3 W ostatnich latach podobne szacunki przygotowały także kraje rozważające wprowadzenie BDP. Szwajcarzy dyskutowali wprowadzenie dochodu podstawowego w wysokości 30 tys. CHF na osobę rocznie (około 200 mld wydatków rocznie), a Finowie 800 EUR na osobę miesięcznie (po prostym pomnożeniu daje to kwotę 52,2 mld rocznie - zob. Ceglarz 2016).

${ }^{4}$ Kwota podana przez Widerquista to około 3\% amerykańskiego PKB, obliczenia Szumlewicza to około 11,5\% polskiego PKB. Gdyby wydatki na polski BDP równały się trzem procentom PKB, wyniosłyby w 2015 roku 29 miliardów dolarów. Oznacza to, że obliczenia ogólnych wydatków są przeszacowane o ponad 3/4. 
do negatywnego opodatkowania ${ }^{5}$. W 2002 roku Stephen Clark obliczył koszty owego negatywnego podatku dla USA na 250 mld USD. Inny autor o tym samym nazwisku, Charles Clark oszacował w 2003 roku koszty BDP na 1,98 biliona dolarów ${ }^{6}$. Bazując na jego obliczeniach, Phillip Harvey (2012) porównał koszty obydwu omawianych tu programów. Uwzględniając zmiany wartości pieniądza, obliczył, że w 2011 roku koszty dochodu podstawowego bezpośrednio finansowanego z budżetu wyniosłyby 2,87 biliona dolarów, zaś koszt negatywnego podatku wyniósłby około 1,40 biliona dolarów. Natomiast wydatki na proponowany przez Harveya program gwarantowanego zatrudnienia (wzbogaconego o pewne dodatkowe działania redystrybucyjne) wyniósłby niespełna 700 miliardów dolarów.

Można w tym miejscu nadmienić, że koszt programu gwarancji zatrudnienia jest w sposób oczywisty uzależniony od stopy bezrobocia, koniunktury gospodarczej oraz czynników sezonowych. Wysokość wydatków zależy więc - oprócz wielkości makroekonomicznych - w dużej mierze od istniejącej luki zatrudnienia (por. Harvey 2007, 2011, 2012). Koszt dochodu podstawowego jest również uzależniony od czynników makroekonomicznych (np. aktywności zawodowej, ściagalności podatków itp.), ale poza tym głównie od zmiennych demograficznych (migracje, dzietność).

Naszym zdaniem można bezpiecznie przyjąć, że koszty obydwu programów przewyższają obecne wydatki rozwiniętych systemów polityki społecznej, z tym że BDP krótkookresowo kosztuje mniej w przeliczeniu na beneficjenta, a prawdopodobnie więcej w liczbach bezwzględnych. Natomiast GZ jest programem droższym w przeliczeniu na uczestnika, ale - przy założeniu umiarkowanej luki zatrudnienia - ogólnie tańszym i, co ważniejsze, uzależnionym od koniunkturalnych potrzeb. O ile dochód podstawowy ma zostać wprowadzony dla wszystkich obywateli, w żadnej jego wersji nie ma mowy o ograniczeniu horyzontu czasowego jego wypłacania. Przeciwnie, najczęściej podkreśla się jego permanentny charakter. Cele programu gwarancji zatrudnienia także nie zakładaja jego przerwania, lecz jego koszty sa - jak sygnalizowaliśmy - zmienne w czasie i uzależnione od luki w zatrudnieniu (co więcej, w większości propozycji zakłada się spadek nakładów na skutek poprawy jakości prac dostępnych na rynku - będziemy rozwijać ten wątek w kolejnych paragrafach). Harvey (2007) podkreśla, że od kosztu tego programu należy odliczyć niektóre transfery dla długotrwale bezrobotnych (które siłą rzeczy znikna) oraz doliczyć do niego przychody z opodatkowania pracy w ramach programu, a także zyski

\footnotetext{
${ }^{5}$ Propozycja Widerquista ma tę wadę, że jest - jak ujmuje to sam autor - ,zawieszona w próżni”. Oznacza to, że nie znajdziemy w tym opracowaniu kalkulacji dotyczącej innych wydatków budżetowych, a jedynie szacunek budżetowego kosztu netto dla samego BDP. Dlatego też w dalszej części artykułu będziemy opierać się na kalkulacji Harveya, pisząc o GZ jako programie tańszym.

${ }^{6}$ Harvey, przytaczając Clarka, pisze o trylionie, ale ze względu na różnicę skali (kraje anglosaskie stosują tak zwaną skróconą skalę wielkich liczb) warto wyjaśnić, że mowa o bilionie (10 do 12 potęgi), nie trylionie (10 do 18 potęgi).
} 
ze sprzedaży usług i produktów wytworzonych podczas jego trwania ${ }^{7}$. Podobny mechanizm powinien zadziałać również w odniesieniu do BDP: zdecydowanie większa część istniejących świadczeń zostanie zniesiona, a zastrzyk koniunkturalny i nowy wzrost gospodarczy pokryja część kosztów programu.

\subsection{Finansowanie}

Ogólnie można przyjąć za Tcherneva (2013), że obydwa rozpatrywane rozwiązania będa potencjalnie finansowane $z$ własności wspólnej na jeden $z$ trzech sposobów: zastapienie obecnych wydatków, zwiększanie długu (deficyt budżetowy) lub zwiększenie przychodów skarbu państwa (wzrost podatków). Pierwszy z wymienionych sposobów zostanie omówiony poniżej ${ }^{8}$, ale już tu można przyjać, że z całą pewnością nie pokryje wszystkich potrzeb związanych z BDP czy GZ. Konieczne jest więc zwiększenie deficytu lub podniesienie podatków.

Podniesienie podatków wiąże się z pewnymi konkretnymi niedogodnościami. W Polsce - zgodnie ze sprawozdaniem Ministerstwa Finansów za rok 2015 - ogromna część dochodów budżetu (89\%) pochodzi z podatków, przy czym większość z podatków pośrednich. W tej wielkości prawie $3 / 4$ to przychody z podatków od konsumpcji (VAT, akcyza, podatek od gier), a jedynie niecałe $10 \%$ to podatki od osób prawnych. Oznacza to, że podniesienie bezpośrednich podatków najbogatszym i finansowanie opisywanych programów tylko z tego źródła jest politycznie trudne. Z kolei zwiększanie podatków pośrednich jest pewniejsze i łatwiejsze polityczne, lecz zdecydowanie mniej progresywne (a na progresywności zależy dużej części zwolenników obydwu rozwiązań). Można oczywiście zakładać zwiększoną progresję podatków pośrednich (np. VAT-u stanowiącego 50\% polskich dochodów podatkowych), lecz wiąże się z tym ryzyko subsydiowania ekskluzywnej obłożonej największym VAT-em - konsumpcji za granicą. Oparcie dużych wydatków z budżetu na opodatkowaniu osób fizycznych (17,3\% przychodów podatkowych w 2015 roku) rodzi z kolei - zwłaszcza w przypadku BDP - pytanie: jak zachować poparcie dla systemu, który zakłada własne utrzymanie ze źródeł, które chce podważyć (zob. Tcherneva 2013)? Rozwiązaniem proponowanym w niektórych wersjach BDP jest wprowadzenie jednolitej stawki podatkowej przy pozostawieniu dużej kwoty wolnej

\footnotetext{
7 Uruchomienie Planu Jefes w Argentynie zwiększyło PKB o 2,5\%, co czyni ten program dochodowym z perspektywy budżetu państwa (Wray 2006), ale nie pozbawionym wad (Gasparini, Haimovich i Olivieri 2009). Odpłatność towarów i usług wypracowanych w ramach programu gwarancji zatrudniania jest sprawa kontrowersyjna. Harvey $(2011,2012)$ przedstawia swoje szacunki kosztów GZ, zakładając zerowe przychody ze sprzedaży dóbr i usług wytworzonych w programie.

${ }^{8} \mathrm{~W}$ kontekście pozostałych wydatków budżetowych takich jak renty, emerytury, ubezpieczenia społeczne.
} 
od opodatkowania, co ma prowadzić do uzyskania realnej progresji (Avivar 2017). Gdyby w Stanach Zjednoczonych ustanowić taki podatek w wysokości 40\%, skorzystałoby na tym 80\% podatników (Cooper 2014). Hiszpańscy zwolennicy tego rozwiązania szacują podobnie: postulując 49,5\% podatek liniowy, zakładają spadek obciążeń dla 70-80\% procent podatników (dokładniej mówiąc - dla 70\% podatników i 80\% obywateli [Arcarons i in. 2015]).

Zwolennicy bezwarunkowego dochodu podstawowego przyjmuja następująca argumentację: wprowadzenie tego świadczenia zapewni wszystkim obywatelom (lub rezydentom, w zależności od propozycji) podstawowe środki utrzymania i jednocześnie doprowadzi do bardzo znacznego zastrzyku popytowego. W konsekwencji osoby zajmujące najmniej uprzywilejowane miejsca w społecznym podziale pracy będą mogły zrezygnować z zatrudnienia i utrzymać się dzięki BDP. W tym samym czasie popyt wygenerowany dzięki transferowi olbrzymiej ilości gotówki spowoduje, że właściciele przedsiębiorstw będą musieli zareagować zwiększoną dostawą usług i towarów na rynek. Jednakże, aby to było możliwe, nie będą mogli pozwolić na spadek sił produkcyjnych w wyniku odpływu siły roboczej. W krótkim czasie nastapi więc korekta początkowego odpływu pracowników i powrót wielu osób do aktywności zawodowej przy zwiększonej sile przetargowej i podniesionych wynagrodzeniach (por. np. Szlinder 2013). Przypuszczenia te potwierdzaja eksperymenty związane $\mathrm{z}$ wprowadzeniem quasi-BDP ${ }^{9} \mathrm{w}$ krajach wysoko rozwiniętych oraz świadczenia warunkowe funkcjonujące w krajach rozwijających się. W przypadku tych ostatnich na przykład brazylijskiej Bolsa Familia (zob. De Brauw i in. 2015 oraz Soares i in. 2010) wiele wskazuje na stabilna podaż pracy beneficjentów, choć i na pewne ważne zmiany w jej strukturze. Eksperymenty prowadzone w Stanach Zjednoczonych i Kanadzie w latach siedemdziesiątych pokazały - wbrew oczekiwaniom krytyków - raczej zmianę czasowego wymiaru odpłatnej pracy, ale względna stabilność ogólnej podaży pracy (z tym że spadek partycypacji dotyczył częściej kobiet niż mężczyzn [Pasma 2009, Robeyns 2001]). Podobnie irańska renta obywatelska wprowadzona w postaci powszechnego dodatku pieniężnego rekompensującego wzrost cen energii nie zmniejszyła podaży pracy (Salehi-Isfahani, Mostafavi-Dehzooei 2017) ${ }^{10}$.

Niektórzy krytycy wprowadzenia BDP przyjmują analogiczną argumentacje (Tcherneva 2013), podkreślając związane z tą koncepcją ryzyko inflacyjne. Niezależnie

\footnotetext{
9 Piszemy quasi-BDP, bowiem wszystkie dotychczasowe programy eksperymentalne wzorowane na tym pomyśle miały charakter ograniczony lokalnie, a więc nie udzieliły one odpowiedzi na kluczowe pytanie o makrospołeczne i makroekonomiczne konsekwencje dochodu podstawowego.

10 Być może warto dodać - w kontekście przytoczonych wyżej argumentów Macieja Szlindera - że transfer ten nie zwiększył również podaży pracy. Szczególnie udział kobiet w rynku pracy pozostał stabilny, co oznacza, że powszechny transfer gotówkowy wcale nie wpłynął na siłę przetargową najbardziej nieuprzywilejowanych pracowników (a właściwie pracownic).
} 
od źródła finansowania „wzrost wynagrodzeń i cen zredukuje realną wartość dochodu pochodzącego z BDP, i aby utrzymać poziom życia jego beneficjentów, świadczenie będzie musiało wzrosnąć, wymuszając kolejną rundę wzrostu wynagrodzeń i cen" (Tcherneva 2013, 71-72). Rosnąca inflacja uderzy w pierwszej kolejności w najmniej uprzywilejowanych, najgorzej wynagradzanych i żyjących z samych transferów publicznych (Tcherneva 2006). Cytowana autorka rozwija tę argumentację, podnosząc następująca kwestię: jakie konsekwencje będzie miał podział obywateli na płatników netto do systemu podatkowego (pracujących i otrzymujących BDP) i żyjących jedynie $z$ transferu generowanego przez ten system (zob. też Husson 2011)? Nawet na gruncie założeń wynikających z teorii wartości opartej na pracy (zob. Avivar 2017) uzyskanie środków na wypłatę BDP pochodzić będzie, ostatecznie, z pracy zarobkowej pracowników najemnych (przyswajanej w postaci wartości dodatkowej). Zatem póki system będzie funkcjonował w gospodarce kapitalistycznej, obowiązywał będzie podział na pracujących zarobkowo i żyjących tylko z dochodu podstawowego. Tcherneva $(2013,70)$ przytomnie odnotowuje poważne ryzyko pokusy nadużycia związanego z możliwą jazdą na gapę: „innymi słowy, BDP chce opodatkować przychody, które są obecnie generowane w procesach produkcji oraz zatrudnienia i redystrybuować je wszystkim, bez warunku udziału w procesie wytwarzającym te przychody".

Argument ten można przedstawić w zbanalizowany sposób, sprowadzając wszystko do „życia na koszt innych”. Nie to mamy tu na myśli. Istnieje bogata literatura dowodząca negatywnych efektów społecznych sytuacji, w której jednostki moga korzystać z określonego dobra publicznego (tu bezwarunkowy dochód podstawowy) bez konieczności ponoszenia kosztów jego utrzymania (Olson 2012, Boudon 2008). Polemika z opartymi na indywidualizmie metodologicznym stanowiskami odwołującymi się do zekonomizowanej wersji problemu gapowicza wymaga odwołania się - w rozpatrywanym przypadku do etycznego wymiaru pracy, do pozadochodowych argumentów przemawiających za praca zarobkową. Tymczasem wydaje się, że zwolennicy BDP są w tym względzie niekonsekwentni. Przykładowo Guy Standing (2012) deklaruje, że naczelny problem współczesnych społeczeństw nie sprowadza się już do zapewnienia wszystkim pracy, tylko do zapewnienia dochodu. Niektóre jego wypowiedzi wprost sugeruja, że widzi on w pracy najemnej przede wszystkim znój, wysiłek i eksploatację (2013). Standing i inni zwolennicy dochodu podstawowego podkreślaja, że pozwoli on zasypać symboliczną przepaść między praca zarobkową i pracą nieprzynosząca dochodu, doceniając szczególnie tę ostatnią. Argument ten jest jednak bronią obusieczna. Jeśli dochód podstawowy rzeczywiście ma spowodować docenienie nieopłacanej pracy (np. pracy domowej kobiet) za pomocą transferu gotówki, to rodzi się pytanie: dlaczego nie wyceni jej zgodnie $z$ wartością rynkową? BDP jako świadczenie podstawowe wycenia omawiane prace na poziomie minimum egzystencji, 
co moralnie i empirycznie jest niewłaściwe (w sprawie wyceny prac domowych zob. np. Błaszczak-Przybycińska 2014).

Wracając do problemu jazdy na gapę: jeśli mimo wszystko każda czynność społecznie użyteczna (wytwarzająca wartość użytkowa) uzyska w społeczeństwie BDP zbliżoną sankcję moralną, to jak uzasadnić potrzebę pracy zarobkowej, a tym samym jak obronić się przed pokusą nadużycia? Mówiąc prościej, symboliczne uznanie czynności pozazarobkowych wydaje się wattpliwe w systemie utrzymywanym z pracy zarobkowej. BDP finansowany z opodatkowania pracy i majątku (co oznacza w ekonomii marksowskiej tyle, co zakumulowane i przywłaszczone efekty pracy) prowadzi do podziału na pracujących zarobkowo i żyjących z transferów gotówkowych (Husson 2011).

Cytowany wyżej efekt brazylijskiego programu Bolsa Familia (De Brauw i in. 2015) zdaje się potwierdzać tę intuicję. Badacze zauważyli względnie stabilną podaż pracy wśród jego beneficjentów, lecz dostrzegli znaczące, tj. około 8\% przesunięcie (zwłaszcza w miastach) w kierunku sektora nieformalnego. Co więcej, inny zespół badaczy (Oliveira $\mathrm{i}$ in. 2007) doszedł do wniosku, że zagregowana konsumpcja gospodarstw domowych otrzymujących świadczenie nie wzrosła (choć docenione zostały wydatki na potrzeby najmłodszych członków rodzin). Może to oznaczać, że transfer gotówkowy zmienił strukturę dochodów rodziny, prawdopodobnie ograniczając pracę dzieci (Soares i in. 2010) i modyfikując podaż pracy na styku sektora formalnego i nieformalnego. Oczywiście należy wziąć pod uwagę, że brazylijski program ma charakter warunkowy, a więc niejako zachęca do ukrywania lub zaniżania dochodów w nadziei na dalsze otrzymywanie świadczeń ${ }^{11}$. BDP nie generuje takiej pułapki (w przypadku pułapki bezrobocia zob. Gilroy, Heimann i Schopf 2013), czym góruje nad niektórymi sprawdzonymi empirycznie programami zatrudnienia (Gasparini i in. 2009), lecz wcale nie jest pewne to, że nie stworzy innego rodzaju zachęty do przechodzenia do szarej strefy. Ci, których dochody będą balansować na granicy progu, po przekroczeniu którego osoby te będą dopłacały do systemu, mogą mieć silną motywację do ukrywania części własnych przychodów i do przechodzenia do gospodarki nieformalnej. Nie bez znaczenia jest również presja kapitalistów, którym ten stan rzeczy będzie bardzo na rękę. Co się tyczy tych ostatnich - potencjalne podatki od majątku mogą ich skłonić do ukrywania części zgromadzonych zasobów finansowych i trwałych.

Podobnego problemu nie mają zwolennicy gwarancji zatrudnienia, którzy konsekwentnie podkreślają pierwszoplanowe znaczenie formalnej pracy zarobkowej dla: zwalczania ubóstwa, podnoszenia własnej wartości w grupach nieuprzywilejowanych oraz zapewnienia makroekonomicznej stabilności. Matthew Forstater (2000), powołując się obszernie na Vickrey'a (1994), dowodzi użyteczności programu GZ, rozumianego

\footnotetext{
${ }^{11} \mathrm{~W}$ istocie cytowani autorzy tak właśnie interpretują otrzymane wyniki (De Brauw i in. 2015).
} 
jako mechanizm kreowania zatrudnienia w oparciu o recyklingu oszczędności. Konieczna wysokość deficytu budżetowego jest w tej propozycji dyktowana luką w zaoszczędzonym majątku netto, a ograniczana realnymi potrzebami mierzonymi liczbą osób zgłaszających się po prace gwarantowana. Kreując stanowiska w obszarach niezagospodarowanych przez rynek (np. w ochronie środowiska, konserwacji infrastruktury, pracy opiekuńczej), GZ nie powinna konkurować z rynkowymi stanowiskami pracy ani z innymi etatami w sektorze publicznym, tylko wypełniać istniejącą lukę w wykorzystaniu oszczędności (Vickrey 1994, 446). Ponieważ na cały mechanizm można nałożyć ograniczenie finansowania z deficytu tylko do poziomu wypełnienia luki między potrzebami a aktualnymi oszczędnościami, nie wywoła on inflacji (poza niewielkim początkowym wzrostem cen). Ponadto nieinflacyjny charakter GZ polega także na tym, że opiera się ona nie tylko na stymulowaniu zagregowanego popytu, ale jednoczesnym oddziaływaniu na podaż (dostarczaniu towarów i usług na rynek). Co więcej, miejsca pracy oferowane w takim programie oraz wypłacane wynagrodzenia będa mogły stać się punktem odniesienia dla sektora prywatnego (i reszty publicznego), wyznaczając dolną granicę wynagrodzenia (lub w innym języku teoretycznym - minimalną cenę dzierżawy siły roboczej) i stabilizując w ten sposób nie tylko wynagrodzenia i warunki pracy, ale również cały system monetarny (zob. też Tcherneva 2006, Wray 1998). Pracownicy będą wciąż dostępni dla sektora prywatnego i kiedy zapotrzebowanie na pracę będzie rosło (zmniejszy się luka między oszczędnościami a realnymi potrzebami), może (a nawet powinien) nastapić odpływ pracowników na inne stanowiska (Forstater 2000). Forstater podkreśla, że aby zapewnić tę elastyczność, program może celowo dobierać branże, metody produkcji i wykorzystywane surowce, żeby dodatkowo otwierać możliwości przepływu pracowników z programu na otwarty rynek pracy (przy zachowaniu regulacji wynagrodzenia w ramach programu). Taką rolę pośrednio pełniło japońskie Ministry of International Trade and Industry, przemianowane w 2001 roku na Ministry of Economy, Trade and Industry.

Krytycy tak pomyślanych projektów GZ akcentują doniosłość zmian w rozwiniętych gospodarkach zachodnich dwudziestego i dwudziestego pierwszego wieku. W pierwszej połowie ubiegłego stulecia stosunkowo łatwo było zorganizować masowe i tanie miejsca pracy $\mathrm{w}$ infrastrukturze i przemyśle ciężkim, tymczasem współczesny zmechanizowany i zautomatyzowany kapitalizm nie wymaga już tak dużej liczby pracowników niskowykwalifikowanych, czyniąc projekty GZ trudnymi w realizacji. Obiekcja ta jest, naszym zdaniem, chybiona $z$ trzech powodów. Po pierwsze, prosta praca manualna przy projektach infrastrukturalnych (szczególnie w krajach peryferyjnych i półperyferyjnych jak Polska), czy przy usuwaniu skutków katastrof naturalnych, wciąż może angażować rzesze pracowników. Po drugie, współczesne projekty gwarantowanego zatrudniania planowo odchodzą od opierania się na niskowykwalifikowanej pracy, aby nie tworzyć pułapek dla ich beneficjentów. Po trzecie, oparta na bezpośrednich relacjach interpersonalnych praca 
w usługach nie powinna być o wiele bardziej kapitałochłonna niż praca manualna w przemyśle czy ta przy projektach infrastrukturalnych. Ponadto nieść powinna ze sobą tę korzyść, że oprócz samego zatrudniania może pozytywnie wpływać na zaspokajanie potrzeb w społecznościach lokalnych (np. opieka nad chorymi lub seniorami daje ich nominalnym opiekunom - najczęściej członkom rodzin - więcej czasu wolnego).

Naszą uwagę zaprząta jednak inna luka w argumentacji zwolenników GZ. Otóż trudno oprzeć się wrażeniu, że również w tym mechanizmie tkwi pewne ryzyko wzrostu cen. Zwracał na to uwage Michał Kalecki (1979 [1944], 356), pisząc: „w warunkach pełnego zatrudnienia siła przetargowa związków zawodowych bardzo wzrośnie. Może więc wystąpić spontaniczna tendencja do wzrostu płac nominalnych, co będzie prowadzić do podwyżek cen [...]", a to z kolei do dalszego wzrostu płac. Jeżeli płace w programie GZ miałby być stabilne (nie rosnać), to jaka byłaby odpowiedź projektantów programu na wzrost wydajności pracy? Alternatywą dla wzrostu płac jest spadek cen, a tego się tu nie zakłada (wymagałoby to planowania cen). Oznacza to więc, że albo będziemy zdani na spiralę wzrostu cen podobną do opisanej w odniesieniu do BDP, albo nastapi ograniczenie wydatków z dochodów innych niż płace. Ograniczenie inwestycji nie byłoby pożądane, musi więc nastapić ograniczenie konsumpcji z dochodów kapitalistów i rentierów, które można uzyskać za sprawą niektórych podatków dochodowych lub podatków majątkowych (Kalecki 1979 [1944]) ${ }^{12}$. Ostatecznie program gwarancji zatrudnienia wymaga ostrożnego planowania, tak aby nie zdławić inwestycji prywatnych, nie generować szarej strefy (zwłaszcza podatkowej) i jednocześnie zmniejszyć prywatną konsumpcję przedsiębiorców.

\section{GZ i BDP a inne świadczenia społeczne}

BDP stanowi znaczaca, by nie powiedzieć rewolucyjna, zmianę dotychczasowej polityki społecznej, która oparta jest na warunkowych świadczeniach pieniężnych i niepieniężnych. Negatywne aspekty programów socjalnych w postaci, w jakiej występowały w przeszłości, czy występują współcześnie, są wyśmienicie rozpoznane i ich krytyka zdaje się więcej niż zasadna. Chodzi przede wszystkim o stygmatyzację osób korzystających ze świadczeń socjalnych, występującą od samego początku funkcjonowania programów pomocowych (w kontekście planu Beveridge'a zob. Baranowski 2015, 150-151). W tym kontekście negatywnie naznaczone zostaja w przestrzeni społecznej osoby defaworyzowane przez

\footnotetext{
12 Alternatywą niedostrzeganą przez Kaleckiego jest również ograniczanie czasu pracy przy stałym wynagrodzeniu (zob. Husson 2011). Wrócimy do tego w dalszej części tekstu.
} 
sam fakt korzystania z tego instrumentu pomocy socjalnej, a dodatkowym elementem wzmacniającym owo napiętnowanie są stosowane procedury. Test niskiego dochodu łącznie z deklaracją gotowości podjęcia pracy, jak również z obowiązkiem systematycznego „meldowania się” w określonej placówce, potęgują zjawisko stygmatyzacji, które w rzeczywistości przyczynia się do niekorzystania $\mathrm{z}$ tak skonstruowanego mechanizmu. Trzeba również mieć na uwadze, że obecnie funkcjonujące systemy świadczeń tworza, jak określił to Ryszard Szarfenberg (2014, 24), „złożoną strukturę warunkowości, która w przypadku modelu proceduralno-dyscyplinującego wymaga aparatu gromadzenia informacji, sprawdzania ich wiarygodności, wydawania decyzji o zastosowaniu sankcji, a następnie ich skutecznego przeprowadzenia". Tak rozumiane biurokratyczne procedury skłaniaja do zadania pytania o efektywność ekonomiczną wydatkowania publicznych pieniędzy. Z drugiej strony, sam system sankcji wobec najbardziej potrzebujących obywateli wydaje się problematyczny i etycznie wattpliwy, szczególnie gdy stosowane testy oceniające „stają się narzędziem monitorowania, kierowania i karania” (Standing 2015, 248).

Gdy dodamy do tego następny argument, związany z potencjalną trudnością uzyskania informacji na temat warunkowej pomocy, ponieważ kryteria formalne ulegaja zmianie, wymagają określonej wiedzy i umiejętności aplikowania, a nade wszystko spoczywają na barkach osób potrzebujących (często słabo wykształconych), to krytyka obecnego status quo wydaje się nieodzowna. Ponadto samo dotarcie świadczeń do potrzebujących jest problematyczne. Wspomniane wcześniej warunkowe transfery gotówkowe w Ameryce Południowej (m.in. Bolsa Familia, Oportunidades czy Chile Solidario) zostały pod tym względem porównane przez Soaresa i jego wspólpracowników (2010). Wniosek z tych zestawień jest następujący: im szersze wsparcie program oferuje, tym większe generuje kłopoty z trafieniem do adresatów, wraz z rozszerzaniem się programu zwiększa się zatem liczba osób uprawnionych, ale odrzuconych $z$ systemu ${ }^{13}$.

Kwestia emerytur w kontekście BDP stanowi bardzo ważne zagadnienie, gdyż zdecydowana większość środków w wydatkach socjalnych pokrywa to właśnie świadczenie pieniężne. Problem starzenia się społeczeństw rozwiniętych nie jest również bez znaczenia. Zwolennicy dochodu podstawowego opowiadają się za emeryturą obywatelską, do której prawo posiadaliby członkowie danego kraju po osiagnięciu ustalonego wieku. Jej wysokość powinna, podobnie jak w przypadku BDP, zapewnić minimum niezbędne do egzystencji lub minimum społeczne dla osoby w wieku poprodukcyjnym, wyznaczane przez odpowiednie agendy. Jak trafnie zauważa Harvey (2012), połączenie BDP z reformą

13 Przykładowo argentyński program Oportunidades bardziej restrykcyjnie sprawdzał „należność” świadczeń niż brazylijska Bolsa Familia, skutkiem czego rzadziej przyznawano świadczenie osobom do tego nieuprawnionym, ale również częściej pomijano uprawnionych (41\% uprawnionych otrzymywało świadczenie w Brazylii, z kolei 30\% w Argentynie). 
systemu emerytalnego mimo wszystko prowokuje pytanie o zastępowalność dochodu ustającego w momencie przejścia na emeryturę - przez świadczenie pieniężne. Sam dochód podstawowy nie może spełnić tej funkcji, a uzupełnienie go o dodatkowe świadczenia pozostawia problem emerytur w postaci podobnej do dzisiejszej.

Wprowadzenie dochodu podstawowego będzie oznaczało w praktyce dogłębną i strukturalną rekonstrukcję obecnego systemu polityki społecznej (ponieważ część świadczeń stanie się zbędna, jak np. zasiłki dla bezrobotnych czy dodatki w postaci pomocy rzeczowej), ale nie jej likwidację (np. opieka zdrowotna czy edukacja). W tym miejscu rodzi się wiele pytań na temat zakresu i kształtu systemu opieki społecznej po wprowadzeniu dochodu podstawowego oraz innych praw i rozwiązań, które stanowią uzupełnienie współczesnych, niedoskonałych instytucji welfare state (np. płaca minimalna). Stanowią one zasadnicze źródło potencjalnych obaw związanych z propozycją BDP, jako że rzecznicy i entuzjaści owej propozycji nie prezentuja jednorodnych stanowisk w tej materii, co jeszcze bardziej pogłębia obawy sceptyków i/lub niezdecydowanych.

Przyjrzyjmy się hipotetycznej sytuacji na rynku pracy po wprowadzeniu dochodu podstawowego. Zwolennicy BDP właściwie jednogłośnie powtarzają, iż sytuacja przetargowa pracobiorców obydwu płci zdecydowanie się polepszy, czego konsekwencją będą wyższe płace oferowane im przez pracodawców. Polemizując z krytycznymi uwagami Hussona i Barry'ego w tej kwestii, Maciej Szlinder stwierdza:

\begin{abstract}
Wzrost zatrudnienia wpłynąłby $[\ldots]$ na zwiększenie pozycji przetargowej pracowników w negocjacjach płacowych $\mathrm{z}$ pracodawcami. Groźba bezrobocia przestałaby zmuszać pracowników do ustępstw, po pierwsze dlatego, że łatwiej byłoby im znaleźć zatrudnienie w innym zakładzie pracy, a po drugie, ponieważ nawet gdyby nie znaleźli satysfakcjonującego miejsca pracy, dochód podstawowy chroniłby ich przed ubóstwem. Pracodawcy musieliby zatem oferować pracownikom wyższe płace, co znacząco zmieniłoby układ zachęt istotnych z perspektywy decyzji o podjęciu pracy zawodowej (Szlinder 2014, 250).
\end{abstract}

W powyższej argumentacji jest wiele nieuzasadnionego optymizmu, pomijającego istotne „szczegóły” towarzyszące propozycjom BDP, jak chociażby: kwestia płacy minimalnej po wprowadzeniu tego projektu14; zupełnie pominięta kwestia migrantów zarobkowych, którzy ze względów formalnych pozbawieni byliby prawa do BDP, a pozostawaliby aktywni na rynku pracy, co mogłoby doprowadzić jednak do osłabienia sytuacji przetargowej „pełnoprawnych” obywateli i powstania dualnego rynku pracy; nie zostaje tu również uwzględniony wzmiankowany wcześniej problem przechodzenia do gospodarki nieformalnej.

\footnotetext{
14 Jej brak łatwo może doprowadzić do „subsydiowania płac” (por. Husson 2011).
} 
Mając na uwadze historyczne zdolności adaptacyjne systemu kapitalistycznego, w ramach którego zakłada się wprowadzenie dochodu podstawowego, nie są to obawy nieuzasadnione. Podobnie ma się rzecz z partycypacją kobiet na rynku pracy, która rzekomo ma się zdecydowanie poprawić, lecz niewiele argumentów empirycznych wzmacnia tę tezę. Zarówno podczas eksperymentów z negatywnym podatkiem dochodowym w Ameryce Północnej w latach siedemdziesiatych, jak i w badaniach weryfikujących skutki warunkowych programów dla najuboższych w Ameryce Południowej, zaobserwowano zmniejszenie aktywności zawodowej kobiet. Dotyczyło to zwłaszcza kobiet najbardziej negatywnie uprzywilejowanych, reprezentujących mniejszości etniczne, pracownic domowych gospodarki nieformalnej (zob. Vollenweider 2013), imigrantek i kobiet mieszkających na wsi. Argentyński program gwarancji zatrudnienia wykazał się na tym polu większą skutecznością, angażując w ostatnim okresie swojego funkcjonowania nawet 70\% kobiet w stosunku do ogólnej liczby uczestników (Wray 2006). Zastępujące ten program świadczenia gotówkowe doprowadziły do całkowicie przeciwnych skutków, zatrzymując część argentyńskich kobiet w domach (Tcherneva 2006).

Zwolennicy GZ są w swych deklaracjach na temat siatki zabezpieczeń socjalnych względnie konsekwentni, także z prozaicznego powodu ich mniejszej liczebności i większej homogeniczności teoretycznej $\mathrm{w}$ porównaniu z propagatorami BDP. W ich przekonaniu gwarancja zatrudnienia wpłynie bezpośrednio jedynie na te świadczenia, które dotycza polityki zatrudnienia. Znikną świadczenia dla bezrobotnych, a warunkowa siatka świadczeń stymulujących zatrudnienie ${ }^{15}$ zostanie zastapiona bezwarunkowym mechanizmem kreowania wakatów. Pośrednio pełne zatrudnienie może oczywiście oddziaływać na inne świadczenia, ale w zamierzeniach jest to raczej wpływ ograniczający wydatki na niektóre cele społeczne, np. pomoc społeczną czy niektóre instytucje, jak choćby wymiar sprawiedliwości.

\section{Wpływ BDP i GZ na poziom nierówności dochodowych, relacji klasowych i stosunków godnościowych}

W ostatnich latach w naukach społecznych na pierwszy plan zaczęly wysuwać się kwestie nierówności gospodarczych oraz ich społecznych i kulturowych konsekwencji. Wielu ekonomistów (np. Piketty 2015a, 2015b), socjologów (np. Therborn 2015), a nawet epidemiologów (np. Wilkinson i Pickett 2011) podkreślało negatywne konsekwencje nierówności dochodowych i majątkowych. W związku z tym zasadne jest pytanie o wpływ

\footnotetext{
15 Mamy na myśli mechanizmy workfare (o neoliberalnej korzeniach), których wiele funkcji sprowadza się do stygmatyzującego monitorowania beneficjentów (zob. np. Wacquant 2009).
} 
BDP oraz GZ na poziom nierówności, jak również na relacje klasowe i stosunki godnościowe.

Zarówno dochód podstawowy, jak i gwarancja zatrudnienia posiadają ograniczone możliwości wpływania na poziom nierówności dochodowych. Wprowadzenie BDP zlikwidowałoby w danym społeczeństwie ubóstwo na olbrzymią skalę (z pominięciem osób nieposiadających statusu obywatela czy rezydenta), lecz zgodnie z intencją zwolenników tego pomysłu, o ile nie spadłaby motywacja do pracy, skala nierówności dochodowych wciąż odzwierciedlałaby specyfikę danego rynku pracy. Przykładowo Maciej Szlinder (2013), powołując się na pojęcia krańcowej skłonności do oszczędzania i krańcowej skłonności do konsumpcji, argumentował w odniesieniu do BDP, że robotnicy najprawdopodobniej skonsumują swój dochód, a kapitaliści oszczędzą. Taki stan rzeczy nie może zmienić kluczowego dla nierówności stosunku między dochodem a majątkiem (zwanym przez Piketty'ego kapitałem, zob. 2015a), zwłaszcza kiedy rozważamy zmianę na korzyść tego pierwszego. W propozycjach zakładających podatek liniowy (Arcarons i in. 2015, Avivar 2017) obecne jest założenie silnej progresji w opodatkowaniu dochodów. Działanie takie zwiększa równość dochodowa, lecz nie musi niwelować nierówności majątkowych. Można powiedzieć nawet więcej: jeśli BDP ma pozytywnie wpłynąć na ogólną koniunkturę gospodarcza, to prawdopodobnie powiększy majątki najbogatszych, poprawi sytuację najuboższych i powiększy oszczędności średnio zarabiających, lecz nie musi tym samym pozytywnie wpłynać na stosunek dochodu do kapitału (Piketty 2015a16).

Jeżeli wraz z wprowadzeniem dochodu podstawowego zniesiona zostałaby płaca minimalna, nierówności dochodowe mogłyby kształtować się na relatywnie wysokim poziomie, z bezwzględnym - nienegowanym tu - atutem bezpieczeństwa społecznego w postaci posiadania środków na życie powyżej progu egzystencji (lub minimum socjalnego). W przypadku GZ, gdzie minimalna wartość płacy powinna być implicite założona, nie występuje ten problem, co nie oznacza, iż szczególnemu spłaszczeniu poddany zostanie poziom nierówności dochodowych. Jeżeli zakładane przez ten program efekty makroekonomiczne zostałyby zrealizowane, ich beneficjentami byliby w równym stopniu kapitaliści, jak pracownicy najemni. Ponieważ główną zaletą GZ w oczach zwolenników MMT ma być stabilizacja systemu monetarnego, a w konsekwencji gospodarki, po tym rozwiązaniu spodziewać się należy - poza pierwszym okresem - raczej niewysokiego wzrostu gospodarczego. Jak wiemy z prac Piketty'ego (2015a, 2015b), ustabilizowany długookresowo (co w pracach tego ekonomisty oznacza uśredniony) na niskim poziomie wzrost dochodu narodowego sprzyja narastaniu różnic majątkowych.

16 Stąd między innymi krytyka Piketty’ego kierowana pod adresem takich wskaźników sumarycznych, jak wskaźnik Giniego. Łączy on w sobie nierówności dochodowe i majątkowe, nie pozwalając dostrzec różnej dynamiki obydwu tych źródeł zaspokajania potrzeb życiowych. 
Naturalnie moglibyśmy rozważyć BDP na poziomie zdecydowanie wyższym od minimum niezbędnego do egzystencji (jak w przypadku propozycji odrzuconej w referendum w Szwajcarii, gdzie zakładano nieopodatkowaną kwotę 2,5 tys. CHF) przy jednoczesnym utrzymaniu płacy minimalnej. $Z$ drugiej strony, nic nie stoi na przeszkodzie, by w propozycji GZ wywindować jej dolna granicę lub, jak w przypadku przytoczonej wcześniej propozycji Kaleckiego (1979 [1944]), naciskać systemowo na zwiększenie udziału płac kosztem zysków w konsumpcji. Zasadnicza różnica pomiędzy tymi koncepcjami pojawia się w kontekście relacji klasowych oraz stosunków godnościowych. Jeśli chodzi o te ostatnie, posłużymy się celowo pojęciem pułapki płacy neutralnej Guya Standinga, czyli ekonomisty, który jest zwolennikiem BDP, by pokazać potencjalna przewagę GZ z godziwą płaca minimalną nad pieniężnymi świadczeniami społecznymi. Otóż wspomniana pułapka polega na tym, że „dochód z pracy nie pokrywa w ich [tj. osób znajdujących się w owej pułapce - przyp. MB i BM] wypadku kosztów jej podjęcia, ponieważ nie tylko traca świadczenia, lecz także muszą zapłacić za opiekę nad dziećmi, dojazdy, odpowiednie ubrania i tak dalej" (Standing 2015, 239). Jest to sytuacja nie do zaakceptowania i stanowi o ułomności - w tym wypadku - funkcjonujących w Wielkiej Brytanii rozwiązań. Jednak kluczowa kwestia w kontekście zestawienia BDP z GZ dotyczy zacytowanej przez Standinga wypowiedzi samotnej matki, wychowującej dwoje małych dzieci, na temat jej bardzo trudnej sytuacji:

\footnotetext{
Byłabym w lepszej sytuacji, gdybym ubiegała się o świadczenia, ponieważ opłaciłabym w ten sposób koszty mieszkaniowe. Jednak nie zrobię tego. Bo chociaż w zasadzie nic nie zarabiam, moja praca nadaje naszemu życiu strukturę, a moje dzieci korzystaja z kontaktów rówieśniczych w klubie malucha. Jakoś sobie radzimy, ale jeśli lodówka się zepsuje, nie mam pieniędzy na zakup nowej (O’Connell 2012, cyt. za Standing $2015,240)$.
}

Funkcja pracy najemnej we współczesnych społeczeństwach nie ogranicza się wyłącznie do uzyskiwania dochodów, choć ten aspekt odgrywa kluczową rolę w kapitalistycznym systemie, ale wiąże się także z szerszym kontekstem społeczno-kulturowym (wspólnota lokalna, rodziną, stosunkami w miejscu pracy - zob. Gourevitch 2016). Prekarne formy zatrudnienia, które spychają szerokie kategorie społeczne w różnorodne formy niepewności, nie zapewniając możliwości zaspokojenia podstawowych i ponadpodstawowych potrzeb, sa patologią obecnego systemu społeczno-gospodarczego. GZ wraz z godziwą płaca za pracę stanowi potencjalne rozwiązanie tego rodzaju problemów, jednocześnie prowadząc do emancypacji przez pracę najemna/zarobkowa. Zwolennicy BDP, krytykując ten postulat, często idą na łatwiznę, odnosząc się do sytuacji, w której praca nie daje możliwości godnego życia, a służy skrajnemu wyzyskiwaniu pracownic i pracowników. Zapominają, że gwarancja 
zatrudnienia nie oznacza przymusu zatrudnienia (Harvey 2012, 13). To tak, jakby krytykować BDP, który nie daje możliwości egzystencji powyżej progu ubóstwa, co jest przecież sprzeczne z samą ideą dochodu podstawowego. Koncepcji gwarancji zatrudnienia zarzuca się również mniejszą niż w przypadku BDP dekomodyfikacje pracy (a nawet jej odwrotność, czyli utowarowienie i przymus pracy). Jest to zarzut w najlepszym razie częściowo słuszny. Istotnie poważnym problemem jest sytuacja, w której określone zatrudnienie nie spełnia oczekiwań osoby je podejmującej i dodatkowo jest mniej społecznie pożądane od np. pozapracowych czynności na rzecz wspólnoty (por. Standing 2013). Jednakże możliwość podjęcia godziwie wynagradzanej pracy dla każdego chętnego (i chętnej) może mieć ogromne znaczenie dla dezalienacji stosunków pracy. Michał Kalecki (1979 [1943]) trafnie wskazywał, że przełamanie mitu każącego wierzyć, iż bezrobocie to nieodzowna część kapitalizmu, jest podstawowa rewolucją kryjąca się za stabilnym w czasie, pełnym zatrudnieniem. Z drugiej strony - jak wspominaliśmy - dochód podstawowy uwalnia od konieczności pracy konkretne jednostki, nie wpływając na społeczną konieczność pracy zarobkowej. Zdaniem Gourevitcha (2016) fakt ten prowadzi do atomizacji jednostek zamiast do działania kolektywnego oraz wzmacnia postawy prokonsumpcyjne zamiast zachęcać do walki o demokratyczne miejsce pracy. Badacz ten uważa, że w propozycji BDP nie ma żadnych mechanizmów pozwalających przezwyciężyć autorytarne stosunki w miejscu pracy.

\section{Postępowy BDP i reakcyjna GZ? Czyli jak wypadają rozpatrywane propozycje pod kątem demontażu/cementowania patriarchalnych stosunków społecznych}

Zwolennicy BDP postrzegaja swoja propozycję jako realne zerwanie z patriarchalizmem stosunków społecznych. Jak stwierdził Philippe Van Parijs (2009, 149), dochód podstawowy „nie tylko zapewnia pewną ochronę przed tyranią szefów, ale też przed tyranią mężów i biurokratów. Dostarcza on skromnej, ale pewnej podstawy życia dla bardziej bezbronnych, np. gdy małżeństwa się rozpadają albo gdy nadużywa się władzy administracyjnej”.

O ile nie budzi wątpliwości fakt, że indywidualnie przyznawany dochód podstawowy stanowi dla kobiet jakąś ochronę przed dominacją mężczyzn w pracy czy domu, to trzeba pamiętać, że te same środki będą wypłacane także osobom płci męskiej. Oznacza to, że podstawowy poziom realizacji potrzeb zostanie zapewniony wszystkim obywatelkom i obywatelom, ale nie zniesie kulturowych wzorców „tyranii” przełożonych, mężów czy biurokratów. Mimo ambicji wyrównywania szans życiowych kobiet, w tym ich karier zawodowych, walka o rzeczywistą równość płci będzie musiała się toczyć dalej w sferze stosunków dominacji w danym społeczeństwie, w rodzinie lub organizacji quasi-rodzinnej, w miejscu pracy itp. Gwarancja zatrudnienia z kolei w punkcie wyjścia włącza szerokie rzesze 
kobiet do systemu pracy, zapewniając (indywidualnie wypłacana) płacę, czyli korzyści analogiczne do BDP, ale dodając do tego inne korzyści w postaci budowania i cementowania relacji społecznych, kontaktów zawodowych, podtrzymywania ciagłości kompetencji czy, generalnie rzecz ujmując, zaangażowania obywatelskiego. W podobnym duchu można interpretować wypowiedź Hussona, podkreślającego, że

\begin{abstract}
[...] kwestia prawa kobiet do pracy jest szczególnie wrażliwa na sprzeczności tez o powszechnym dochodzie. Jeśli praca najemna, to tylko niewola, kobiety powinny być zadowolone, gdy odsuwa się je od pracy, a następnie żądać gwarantowanego dochodu jako kompensaty za swoją aktywność społeczną. Nie sposób jednak nie dostrzec, że to rozumowanie zderza się czołowo z egalitarnymi aspiracjami kobiet w dziedzinie zatrudnienia. Wypłacanie im zasiłku, aby nie pracowały, czy dlatego, że nie pracuja - oto projekt, który wcale nie jest szczególnie postępowy, a powszechny dochód w tym przypadku zaczyna przypominać zasiłek wychowawczy czy nawet bardzo wątpliwą płacę macierzyńską (Husson 2011, 143-144).
\end{abstract}

Klasyczne propozycje pełnego zatrudnienia zakładały gwarancję pracy na pełen etat dla jednej osoby w każdej rodzinie (Packer 1974, 22; Wray 2006), co naturalnie może budzić uzasadnione zastrzeżenia w kontekście patriarchalnych stosunków społecznych. Jednak przewidziano warianty pełnego zatrudnienia i zatrudnienia na pół etatu dla rodzica samotnie wychowującego dziecko lub dla rodzin $\mathrm{z}$ niepełnosprawnymi dziećmi, co może odzwierciedlać indywidualne wybory poszczególnych jednostek (i wychodzić naprzeciw oczekiwaniom tychże, szczególnie w kontekście mniejszych miast czy wsi, często nieposiadających odpowiedniej infrastruktury publicznej w postaci żłobków czy przedszkoli).

Jeśli zaś chodzi o długość czasu pracy, to propozycja np. trzydziestolub trzydziestopięciogodzinnego tygodnia pracy stanowi ważny element refleksji zwolenników programu GZ (Husson 2011, 136-140; Gordon 1997, 829). Dyskusja nad skróceniem czasu pracy, szczególnie w perspektywie wydajności tejże, bezrobocia lub po prostu większej ilości czasu wolnego, który jednostka może dowolnie spożytkować, częściowo koresponduje z zakładanym przez orędowników BDP pozytywnym wpływem ich propozycji na dobrostan psychiczny społeczeństwa. Potwierdzają to wyniki argentyńskiego eksperymentu z lat 20012002, podczas którego gwarancja zatrudnienia przewidziana była na cztery godziny dziennie. Skutkiem tego pracujący mieli do dyspozycji sporo wolnego czasu, który często twórczo wykorzystywali. Ponadto - jak zwracaliśmy uwagę - większość beneficjentów była w istocie beneficjentkami programu. W związku z tym powstawanie nowych miejsc zatrudnienia w dużej mierze dotyczyło czynności opiekuńczych świadczonych na rzecz rodzin innych beneficjentek programu (rozwój programu darmowych usług społecznych). W ramach tego procesu - przy założeniu ograniczonego czasu pracy - docenione zostają zarówno czynności 
zarobkowe, jak i czas wolny, a dodatkowo stymulowany jest rozwój wspólnot lokalnych (Wray 2006). Deklaracje uczestniczek i uczestników w ostatnim okresie działania programu wskazywały, że wolą oni/one otrzymywać wynagrodzenie za pracę niż transfer gotówkowy tej samej wysokości (Tcherneva 2006).

W rozważanym kontekście nie sposób pominać istotnego, w naszej ocenie, elementu gruntownej przebudowy systemu polityki społecznej z punktu widzenia propozycji dochodu podstawowego. Chodzi mianowicie o taką transformację instytucji welfare state, która wpisuje się w proces utowarowienia coraz szerszych obszarów stosunków społecznych. BDP jest propozycją świadczenia pieniężnego, która właśnie z tego powodu pozwala ominąć pułapki warunkowości, zasadnie stanowiące oś krytyki obecnie funkcjonujących rozwiązań. Jest jednak i druga strona medalu omawianej propozycji, dobitnie określona przez Hussona jako „reakcyjna”, ponieważ łącząca się z „prawdziwym odspołecznieniem”. Wedle francuskiego badacza ,projekt postępowy polega na przywracaniu i poszerzaniu pola bezpłatności - na poszerzaniu gwarantowanych praw społecznych pod postacią bezpłatnego udostępniania coraz liczniejszych usług” (Husson 2011, 144). Ta krytyka może być także odniesiona do bardziej subtelnych form przeobrażania polityki społecznej, np. w postaci wielosektorowych projektów (por. Grewiński 2009), ale również do propozycji BDP czy państwa dobrobytu w ogóle (Panitch 2011). Jest to o tyle ciekawy wątek, że badaczki i badacze coraz częściej rozważają zalety stopniowo ograniczanych i wypieranych dóbr wspólnych (Baranowski 2016, Bollier 2014), których pozytywny wpływ na życie jednostek jest nie do przecenienia. BDP można oceniać, przyglądając mu się przez pryzmat poszerzania obszaru utowarowienia, które w rzeczywistości - może nawet jako nieintencjonalna konsekwencja postulatów jego zwolenniczek - ograniczy w dłuższej perspektywie prawa społeczne przez zawężenie dostępu do publicznej oświaty czy systemu opieki zdrowotnej (zob. Mika 2014, Gourevitch 2016). Warto pamiętać o tym aspekcie dochodu podstawowego szczególnie w sytuacji politycznych negocjacji warunków jego wprowadzenia (chodzi o to, by wprowadzenie BDP nie wiązało się ze społecznymi ustępstwami w kwestiach publicznej edukacji, służby zdrowia czy polityki mieszkaniowej).

\section{Polityczne możliwości reform}

Gdy zestawi się GZ z dochodem podstawowym w kontekście aktualnych możliwości wdrożenia obydwu propozycji, wydaje się, że dużo większe prawdopodobieństwo konsensusu politycznego dotyczy pierwszej z propozycji. Po pierwsze dlatego, że z perspektywy historycznej pełne zatrudnienie było skutecznie stosowane w różnych okresach i w gospodarkach na różnym poziomie zaawansowania (np. USA, Argentyna, Holandia). Po drugie dlatego, że w odmiennych perspektywach światopoglądowych, ideologicznych 
czy systemach partyjnych praca jest uznawana za wartość samą w sobie, która szczególnie w kapitalistycznym systemie produkcji nabiera pozytywnego znaczenia (przy wielu możliwych interpretacjach tego wyrażenia). Jednocześnie wydaje się, że pogląd Michała Kaleckiego mówiący o znacznym wzroście siły przetargowej pracowników najemnych, będącym efektem wprowadzenia programu pełnego zatrudnienia, jest wciąż aktualny. W wyniku spodziewanej rekompozycji sił klasowych na korzyść robotników program ten będzie zapewne wywoływał silny opór klas właścicielskich. Idea bezwarunkowego dochodu podstawowego prezentuje się jako mniej kontrowersyjna i częściej pojawia się we współczesnych mainstreamowych debatach politycznych. Wprawdzie w Polsce nie ma dziś znaczącej siły politycznej wspierającej BDP, lecz w innych krajach rozwiniętych pomysł ten jest szeroko dyskutowany, także na scenie politycznej (Kanada, Hiszpania, Francja, Szwajcaria, Finlandia - by wymienić tylko kilka przykładów). Zaznaczyć trzeba jednak, że nawet w krajach przychylnie nastawionych do rozbudowanej funkcji opiekuńczej państwa - takich jak Finlandia - debaty konkretyzujące pożądany kształt BDP trwały kilka dekad (por. Koistinen i Perkiö 2014). Sądzimy, że libertarianie (w pewnych wersjach), liberałowie (Zwolinski 2011, Powell 2011) i znaczna część lewicy są generalnie skłonni (Cooper 2014) poprzeć koncepcję BDP. Od niedawna nawet część wielkiego biznesu z Doliny Krzemowej zdradza się z pomysłem pilotowania własnych eksperymentów z dochodem podstawowym (Wężyk 2017).

Zaznaczmy jednak ponownie, że przeszkodą mogą stać się nieścisłości dotyczące szczegółów propozycji. Liberalne i biznesowe poparcie dla BDP dotyczy najczęściej propozycji zakładających znacząca (lub całkowita) redukcję siatki zabezpieczeń społecznych, podczas gdy siły zaangażowane społecznie, przeciwnie, zakładaja jej utrzymanie i reformę. Krótko mówiąc, trudno oszacować, która propozycja ma większe szanse na polityczną realizację, jednak reformy polityki społecznej w duchu neoliberalizmu, np. welfare-to-work, nie pozostawiają złudzeń. GZ jest pomysłem tańszym i opartym na głęboko zakorzenionym, purytańskim szacunku do pracy, BDP jest - przynajmniej jako hasło polityczne - propozycja prostsza, bardziej działająca na wyobraźnie, a w polskim kontekście także nieobarczoną zaszłościami historycznymi ${ }^{17}$.

\section{Podsumowanie}

Reasumując pięć wymienionych tu kryteriów oceny gwarantowanego zatrudnienia i dochodu podstawowego, należy stwierdzić, że rozstrzygnięcia na korzyść którejś z dwóch przedstawionych koncepcji nie są wolne od kontrowersji i spekulacji. Niemniej jednak niższe

17 W Polsce pełne zatrudnienie przedstawiane jest często jako główny winowajca nieefektywności gospodarczej czasów socjalizmu państwowego. 
koszty, prostsze sposoby finansowania oraz wpływ na istniejąca siatkę zabezpieczeń socjalnych przemawiaja za gwarantowanym zatrudnieniem. W odniesieniu do potencjału niwelowania nierówności społecznych oraz do politycznych możliwości wprowadzenia obydwu programów trudno o jednoznaczne sądy, lecz BDP wydaje się być w nieznacznie lepszej pozycji. Co zaś tyczy się dekomodyfikacji i stosunków godnościowych, zauważyć należy, że jest to zagadnienie niezwykle chętnie podnoszone przez zwolenników dochodu podstawowego, lecz najczęściej z pominięciem istotnych - omówionych wyżej - zastrzeżeń.

Trudno odmawiać transferom gotówkowym skuteczności oddziaływania. Mikrokredyty, indyjskie i namibijskie eksperymenty z dochodem podstawowym czy rodzinne transfery w Ameryce Południowej pokazały, że nawet niewielkie sumy pieniędzy w dyspozycji najuboższych pozwalają im wydźwignąć się ze skrajnego ubóstwa, poprawiają warunki bytowe, stymulują inicjatywy lokalne, zwiększaja partycypację w edukacji dzieci i dorosłych, korzystnie wpływaja na stan zdrowia beneficjentów i przynoszą wiele innych korzyści. Przykładowo brazylijski program Bolsa Familia - liczbę jego odbiorców szacuje się na około 11-12 milionów - doprowadził do redukcji skrajnego ubóstwa o 12\% w skali kraju (Soares $\mathrm{i}$ in. 2010) i znacząco zwiększył partycypację szkolną. To, czego nie udało mu się wyeliminować, to niezadowalające wyniki edukacyjne uczniów pochodzących z rodzin otrzymujących wsparcie. Wskazuje to na ograniczenia transferów pieniężnych zwłaszcza w dziedzinie stosunków godnościowych i powiązanych z nimi stosunków dominacji.

Z drugiej strony, Amartya Sen, wpływowy badacz oraz laureat Nagrody Banku Szwecji im. Alfreda Nobla z 1998 roku, stwierdził, że BDP nie jest najlepszym sposobem walki z ubóstwem w Indiach na tym poziomie rozwoju kraju (zob. BIEN 2017). Mając wiedzę na temat indyjskiego eksperymentu, Sen podkreślił konieczność rozwoju systemu opieki zdrowotnej, edukacji i innych usług świadczonych przez państwo. Rozdanie ludziom pieniędzy przy braku kompleksowego systemu opieki społecznej i przy niedostępności dóbr publicznych nie wydaje się najlepszym rozwiązaniem wieloaspektowych problemów socjoekonomicznych kraju o nie najlepszych wskaźnikach rozwoju społecznego.

Opinia Sena stanowi ważny głos w dyskusji o dochodzie podstawowym, szczególnie gdy spojrzymy na nią od strony poziomu rozwoju gospodarczego i społecznego danego państwa. Istnieje zasadnicza różnica pomiędzy rozwiniętymi gospodarkami, które w zdecydowanej większości charakteryzują się wysoką jakością systemu opieki publicznej (nawet wtedy, gdy jest on w pewnych okresach ograniczany), szeroką dostępnościa powszechnej edukacji, aktywnym społeczeństwem obywatelskim itp., a krajami peryferii czy półperyferii. Eksperymenty realizowane na mała skalę $\mathrm{i}$ w ograniczonym horyzoncie czasowym, choć moga napawać optymizmem, nie daja pełnej i rzetelnej wiedzy na temat konsekwencji tak radykalnych transformacji. Pamiętajmy również, że w odniesieniu do krajów rozwiniętych nie dysponujemy nawet porządnymi eksperymentami, które rzuciłyby 
zdecydowanie więcej światła na to zagadnienie niż czyste spekulacje zwolenników czy przeciwników BDP.

Za programem gwarancji zatrudnienia przemawiają konkretne doświadczenia, spodziewane, stabilizujące konsekwencje makroekonomiczne i relatywnie nieduże koszty (GZ potencjalnie może generować dochody do budżetu). GZ ma pewniejszy wpływ na podaż pracy, a co za tym idzie, na spadek bezrobocia. W przypadku tej propozycji łatwiej także wskazać mechanizm antyinflacyjny oraz przedstawić jej relację z innymi świadczeniami społecznymi (np. Harvey 2012). W konsekwencji łatwiej też przewidzieć wpływ gwarancji zatrudnienia na nierówności społeczne, choć w tym względzie obydwa programy są warunkowo progresywne ${ }^{18}$.

Antyinflacyjny potencjał programu gwarantowanego zatrudnienia wydaje się szczególnie ważny - w przypadku projektu BDP wysoki wzrost cen wymuszałby stały wzrost świadczenia (aby zapobiec utracie realnej siły nabywczej), a tym samym prowadziłby do pułapki inflacyjnej. Ponadto, odnosząc propozycje BDP oraz GZ do stosowanego przez Kaleckiego rozróżnienia na stymulowanie konsumpcji i inwestycje, można przyjąć, że dochód podstawowy oddziałuje (jedynie) na konsumpcję, a praca gwarantowana jest programem inwestycji, stymulującym również siłę nabywczą jego beneficjentów. Z perspektywy niedorozwoju krajów półperyferyjnych i peryferyjnych jedyna droga do nadgonienia centrum i wyrwania się z zależności wobec niego wiedzie przez własne inwestycje (wyraźnie podkreślaja ten fakt ekonomiści Chang 2013 czy Piketty 2015a). W tym sensie rację ma przywołany Amartya Sen, wskazując na pierwszorzędną konieczność rozbudowy infrastruktury społecznej. Jedynie przez inwestycje w edukację, system ochrony życia i zdrowia, instytucje społeczne itp. peryferia moga zmniejszyć swoje różnice względem centrum. Gwarancja zatrudnienia, będąc programem inwestycyjnym, lepiej pasuje do tak zarysowanego celu, podobnie jak dbanie o wysokie standardy pracy i godne płace.

Nieco inaczej mają się sprawy w krajach wysoko rozwiniętych, gdzie ogólnie pojęte instytucje państwa opiekuńczego dobrze funkcjonuja. W tych krajach bezpośredni transfer gotówki może być odpowiedzią na słabości obecnego systemu. Jednakże odpowiedź ta niepozbawiona jest - wskazanych wyżej - wad i wzbudzać może waţliwości. Także gwarancja zatrudnienia nie jest wolna od słabości, z których najpoważniejsza to trudność w zachowaniu konstrukcji utrzymujaccej stale wysoki poziom inwestycji prywatnych i jednocześnie niski poziom konsumpcji kapitalistów (czyli przesuwającej środki z oszczędności i konsumpcji na inwestycje).

Wyobrazić można sobie również taki scenariusz, w którym kraje najbardziej rozwinięte za pomoca poszerzania usług publicznych i reformowania tradycyjnych instytucji

18 Mamy na myśli konieczność szerokiej reformy fiskalnej skierowanej na zwalczenie nierówności i szeroką redystrybucję. 
polityki społecznej doprowadzą do likwidacji ubóstwa i znacznego zwiększenia rzeczywistych wolności osobistych, wyznaczając kierunek rozwoju krajom mniej zamożnym. Wówczas teoretyczne rozważania będą mogły skupić się na bardziej dosadnej i wyrafinowanej krytyce projektu gwarancji zatrudnienia, w efekcie czego powstanie propozycja abstrahująca nie tylko od historycznych ułomności podobnych inicjatyw, ale wychodząca na wprost oczekiwaniom i aspiracjom szeroko rozumianych podmiotów społecznych. 


\section{Wykaz literatury}

Arcarons, Jordi, Antoni Domènech, Daniel Raventós i Lluís Torrens. 2015. „Model finansowania dochodu podstawowego w Hiszpanii”. Tłum. Maciej Szlinder. Praktyka Teoretyczna Marzec 2015. http://www.praktykateoretyczna.pl/model-finansowaniadochodu-podstawowego-dla-krolestwa-hiszpanii/ [dostęp: 01.04.2017].

Avivar, Roberto C. 2017. „Idea Bezwarunkowego Dochodu Podstawowego (BDP) pod odstrzałem neoliberalnej myśli ekonomicznej”.

https:/ / robertocobasavivar.wordpress.com/2017/03/09/idea-bezwarunkowego-dochodupodstawowego-bdp-pod-odstrzalem-neoliberalnej-mysli-ekonomicznej [dostęp: 11.03.2017].

Baranowski, Mariusz. 2015. „Uwarunkowania historyczne welfare state: między kapitalizmem a socjalizmem?”. Chorzowskie Studia Polityczne 9: 141-155.

Baranowski, Mariusz. 2016. „Kryzys społeczeństwa kapitalistycznego a (nowa) kwestia miejska”. Kultura i Spoleczeństwo 60(2): 19-33.

BIEN [2017]. "Amartya Sen: India not ready for a basic income." http://basicincome.org/news/2017/03/nobel-laureate-economist-amartya-sen-india-notready-basic-income/ [dostęp: 25.03.2017].

Błaszczak-Przybycińska, Ilona. 2014. „Wartość pracy domowej - wycena empiryczna na podstawie ogólnopolskiego badania budżetu czasu ludności”. Prace Nankowe Uniwersytetu Ekonomicanego we Wroctawiu 364: 44-59.

Bollier, David. 2014. Think Like a Commoner: A Short Introduction to the Life of the Commons. Gabriola Island: New Society Publishers.

Boudon, Raymond. 2008. Efekt odwrócenia. Niezamierzone skutki dziatań społecznych. Tłum. Agnieszka Karpowicz. Warszawa: Oficyna Naukowa.

Ceglarz, Jakub. 2016. „Bezwarunkowy dochód podstawowy. Czy Polska powinna pójść w ślady Finlandii?".

http://www.money.pl/gospodarka/wiadomosci/artykul/bezwarunkowy-dochodpodstawowy-finlandia,239,0,2043631.html [dostęp: 01.04.2017].

Clark, Stephen C. 2002. "Funding a Basic Income Guarantee Considering Size, Political Viability, and Pipeline." USBIG Discussion Paper 32: 2-11.

Chang, Ha-Joon. 2013. 23 rzeczy, których nie mówiq ci o kapitalizmie. Tłum. B. Szelewa. Warszawa: Wydawnictwo Krytyki Politycznej.

Cooper, Peter. 2014. "Technology Paves the Way for Basic Income More than a Job Guarantee." heteconomist september 2014. http://basicincome.org/news/2014/10/petercooper-technology-paves-the-way-for-basic-income-more-than-a-job-guarantee/ [dostęp: 27 marca 2017].

De Brauw, Alan, Daniel O. Gilligan, John Hoddinott i Shalini Roy. 2015. "Bolsa Familia and Household Labour Supply." Economic Development and Cultural Change 63(3): 423-457.

Forstater, Mathew. 2000. "Savings-Recycling Public Employment: An AssetsBased Approach to Full Employment and Price Stability.” Journal of Post-Keynesian Economics 22(3): 437-451.

Gasparini, Leonadro, Francisco Haimovich i Sergio Olivieri. 2009. "Labor Informality Bias of a Poverty-Alleviation Program in Argentina.” Journal of Applied Economics 12(2): 181-205. 
Gilroy, Bernard, Anastasia Heimann i Mark Schopf. 2013. „Basic Income and Labour Supply: The German Case." Basic Income Studies 8: 43-70.

Gordon, Wendell. 1997. "Job Assurance: The Job Guarantee Revisited." Journal of Economic Issues 31(3): 826-834.

Grewiński, Mirosław. 2009. Wielosektorowa polityka społeczna. O przeobrażeniach państwa opiekuńczego. Warszawa: Wydawnictwo Wyższej Szkoły Pedagogicznej TWP.

Gourevitch, Alex. 2016. "The Limits of a Basic Income: Means and Ends of Workplace Democracy”. Basic Income Studies 11(1): 17-28,

Harvey, Philip. 2007. "Is There a Progressive Alternative to Conservative Welfare Reform?" [Niepublikowany rękopis dostępny online] https://works.bepress.com/philip_harvey/1/ [dostęp: 10.03.2017].

Harvey, Philip. 2011. "Securing the Right to Work at the State or Local Level with a Direct Job-Creation Program.” Big Ideas for Jobs Initiative, Institute for Research on Labor and Employment, University of California at Berkeley, CA. http://www.bigideasforjobs.org/wp-content/uploads/2011/09/Harvey-Full-Report-2PDF.pdf. [dostęp: 04.07.2017].

Harvey, Philip. 2012. "More for Less: The Job Guarantee Strategy.” Basic Income Studies 7(2): 3-18.

Husson, Michel. 2011. Kapitalizm bez. żieczulenia. Studia nad wspótczesnym kapitalizmem, kryzysem swiatowym i strategia antykapitalistyczna. Tłum. Zbigniew Marcin Kowalewski. Warszawa: Instytut Wydawniczy Książka i Prasa.

Kalecki, Michał. 1979 [1944]. „Trzy drogi do pełnego zatrudnienia”. W Michał Kalecki. Dzieła. T.1. Kapitalizm koniunktura i zatrudnienie. Warszawa: Państwowe Wydawnictwo Ekonomiczne: 339-349.

Kalecki, Michał. 1979 [1943]. „Polityczne aspekty pełnego zatrudnienia”. W Michał Kalecki. Drieła. T.1 Kapitalizm koniunktura i zatrudnienie. Warszawa: Państwowe Wydawnictwo Ekonomiczne: 339-349.

Jendrzejczak, Marcin. 2014. „Każdemu od państwa po równo, ale raczej mało”. Obserwator Finansowy Listopad 2014. https://www.obserwatorfinansowy.pl/forma/rotator/kazdemuod-panstwa-po-rowno-ale-raczej-malo/ [dostęp: 01.04.2017].

Koistinen, Pertti i Johanna Perkiö. 2014. "Good and Bad Times of Social Innovations: The Case of Universal Basic Income in Finland." Basic Income Studies 9(1-2): 25-57.

Mika, Bartosz. 2014. „Dochód podstawowy i jego konsekwencje dla świata pracy”. Praktyka Teoretyczna 2(12): 145-169.

Oliveira, Ana, M. H., Monica Andrade, Anne Resende, Clarissa Rodrigues, Roberto Rodrigues i Rafael Ribas. 2007. "The First Results of Baseline Impact Evaluation of Bolsa Familia." W Evaluation of MDS Policies and Programs - Results. Red. Jeni Vaitsman i Rômulo Paes-Sousa. Brasília: SAGI/MDS: 19-66.

Olson, Mancur. 2012. Logika driałania zbiorowego. Dobra publiczne i teoria grup. Tłum. Sebastian Szymański. Warszawa: Wydawnictwo Naukowe Scholar.

Packer, Arnold H. 1974. "Employment Guarantees Should Replace the Welfare System." Challenge 17(1): 21-27. 
Panitch, Vida. 2011. "Basic Income, Decommodification, and the Welfare State." Philosophy and Social Criticism 37(8): 935-945.

Pasma, Chandra. 2009. "Working Through the Work Disincentive." www.cpj.ca/files/docs/orking_Through_the_Work_Disincentive_-_Final.pdf [dostęp: 01.05.2017].

Piketty, Thomas. 2015a. Kapitał w XXI wieku. Tłum. Andrzej Bilik. Warszawa: Wydawnictwo Krytyki Politycznej.

Piketty, Thomas. 2015b. Ekonomia nierówności. Tłum. Andrzej Bilik. Warszawa: Wydawnictwo Krytyki Politycznej.

Powell, K. Brian. 2011. “Two Libertarian Arguments for Basic Income Proposals”. Basic Income Studies 6(2): Article 5.

Robeyns, Ingrid. 2001. „Czy dochód podstawowy odda sprawiedliwość kobietom?” Tłum. Maciej Szlinder. www.praktykateoretyczna.pl/ingrid-robeyns-czy-dochod-podstawowyodda-sprawiedliwosc-kobietom [dostęp: 01.04.2017].

Salehi-Isfahani, Djavad i Mohammad H. Mostafavi-Dehzooei, 2017. "Cash Transfers and Labour Supply: Evidence from a Large-scale Program in Iran”, https://erf.org.eg/wpcontent/uploads/2017/05/1090.pdf

Soares, Fabio, V. Ribas, Rafael, P. Osorio, Rafael, G. 2010. "Evaluating The Impact of Brazil's Bolsa Familia." Latin American Research Review 45(2): 173-190.

Standing, Guy. 2012. "Why a Basic Income Is Necessary for a Right to Work." Basic Income Studies 7: 19-40.

Standing, Guy. 2015. Karta prekariatu. Tłum. Piotr Juskowiak i in. Warszawa: Wydawnictwo Naukowe PWN.

Szarfenberg, Ryszard. 2011. „Tysiąc złotych dla każdego - rozmowa z dr hab. Ryszardem Szarfenbergiem”. Tygodnik Przeglad czerwiec 2011.

https://www.tygodnikprzeglad.pl/tysiac-zlotych-dla-kazdego/ [dostęp: 01.04.2017].

Szarfenberg, Ryszard. 2014. „Rosnąca rola warunkowości pomocy społecznej a dochód powszechny". Praktyka Teoretyczna 2(12): 19-39.

Szlinder, Maciej. 2013b. „Dochód podstawowy z perspektywy ekonomii politycznej Michała Kaleckiego." Nowa Krytyka 30-31: 87-106.

Szlinder, Maciej. 2014. „Powszechny dochód podstawowy - w stronę równości”. Filo-Sofija 24: $247-257$.

Szlinder, Maciej. 2017. „Dochód podstawowy - instrukcja obsługi”. Wywiad Jakuba Dymka. Krytyka Polityczna. 21 lutego. http://krytykapolityczna.pl/gospodarka/dochodpodstawowy-instrukcja-szlinder/. [dostęp: 01.04.2017].

Szumlewicz, Piotr. 2017. „Dochód podstawowy bez złudzeń”. http://www.lewica.pl/?id=31597\&tytul=Piotr-Szumlewicz:-Doch\%F3d-podstawowybez-z\%B3udze \%F1 [dostęp: 04.07.2017].

Tcherneva, Pavlina R. 2006. "Universal Assurances in the Public Interest: Evaluating the Economic Viability of Basic Income and Job Guarantees.” International Journal of Environment, Workplace and Employment 2(1): 69-88.

Tcherneva, Pavlina R. 2013. "The Job Guarantee: Delivering the Benefits That Basic Income Only Promises - A Response to Guy Standing." Basic Income Studies 7(2): 66-87. 


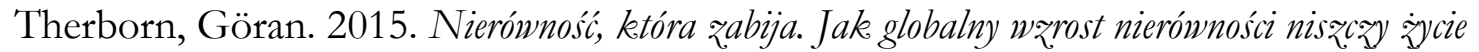
milionów i jak z tym walczyć. Tłum. Paweł Tomanek. Warszawa: Wydawnictwo Naukowe PWN.

Van Parijs, Philippe. 2009. „Dochód podstawowy dla wszystkich”. Problemy polityki społecznej. Studia i dyskusje 11: 139-153.

Van Parijs, Philippe. 2000. “A Basic Income for All.” Boston Review. http://bostonreview.net/archives/BR25.5/vanparijs.html [dostęp: 25.03.2017].

Vickrey, William. 1994. “Why Not Chock-Full Employment?”' Atlantic Economic Journal 25 (1): 39-45.

Vollenweider, Camila. 2013. "Domestic Service and Gender Equality: An Unavoidable for the Feminist Debate on Basic Income." Basic Income Studies 8: 19-41.

Wacquant, Loïc. 2009. Więrienia nęsy. Tłum. Michał Kozłowski. Warszawa: Instytut Wydawniczy Książka i Prasa.

Wężyk, Katarzyna. 2017. „Dochód podstawowy batem na populistów? Znieczulenie nie uzdrowi świata". Magazyn Świateczny Gazety Wyborczej. http://wyborcza.pl/magazyn/7,124059,21357340,dochod-podstawowy-batem-napopulistow-znieczulenie-nie-uzdrowi.html [dostęp: 29.03.2017].

Widerquist, Karl. 2017. “The Cost of Basic Income: Back-of-the-Envelope Calculations." [Niepublikowany rękopis dostępny online] https://works.bepress.com/widerquist/75/ [dostęp: 04.07.2017].

Wilkinson, Richard i Kate Pickett. 2011. Duch równości. Tam gdzie panuje równość, wsaystkim \&̇yje sie lepiej. Tłum. Paweł Listwan. Warszawa: Wydawnictwo Czarna Owca.

Wray, Randall L. 1998. Understanding Modem Money The Key to Full Employment and Price Stability. Northampton (USA)-Cheltenham (UK): Edward Elgar Publishing.

Wray, Randall L. 2006. “Lessons from Argentina's Employment Guarantee.” Economic and Political Weekley June 10th.: 2293-2296.

Wright, Erik O. 2005. "Basic Income as a Socialist Project." http://www.ssc.wisc.edu/ wright/Basic $\% 20$ Income $\% 20 a s \% 20 \mathrm{a} \% 20$ Socialist $\% 20$ Proj ect. Pdf

Zwolinski, Matt. 2011. "Classical Liberalism and the Basic Income.” Basic Income Studies 6(2): Article 10. 
Mariusz Baranowski - adiunkt w Zakładzie Socjologii Zróżnicowania Społecznego Instytutu Socjologii Uniwersytetu im. Adama Mickiewicza w Poznaniu. Ukończył MISH na UAM, w ramach których uzyskał dyplomy z socjologii i filozofii, a także Zarządzanie Zasobami Ludzkimi w Agencji Rozwoju Gospodarczego. Doktorat z socjologii gospodarki w 2009 roku obronił w Poznaniu. Przewodniczący Komisji Socjologicznej Poznańskiego Towarzystwa Przyjaciół Nauk oraz zastępca redaktora naczelnego czasopisma naukowego Studia Krytyczne. Zajmuje się metodologia nauk społecznych, socjologia gospodarki oraz problematyką welfare state.

\section{DANE ADRESOWE:}

Instytut Socjologii

Uniwersytet im. Adama Mickiewicza w Poznaniu

ul. Szamarzewskiego 89 C

60-568 Poznań

EMAIL: mariusz.baranowski@amu.edu.pl

Bartosz Mika - adiunkt w Zakładzie Socjologii Spraw Publicznych i Gospodarki Uniwersytetu Gdańskiego oraz sekretarz redakcji czasopisma filozoficznego Nowa Krytyka. Absolwent studiów socjologicznych na Uniwersytecie im. Adama Mickiewicza w Poznaniu. Doktorat $\mathrm{z}$ nauk humanistycznych $\mathrm{w}$ zakresie socjologii, również na UAM, obronił w październiku 2008 roku. Zajmuje się klasyczną myślą socjologiczną, problematyką socjologii gospodarki oraz zróżnicowania społecznego.

\section{DANE ADRESOWE:}

Instytut Filozofii, Socjologii i Dziennikarstwa

Uniwersytet Gdański

ul. Bażyńskiego 4

80-952 Gdańsk

EMAIL: bartosz.mika@ug.edu.pl

CYTOWANIE: Baranowski, Mariusz i Bartosz Mika. 2017. „Wielokryterialna ocena projektów bezwarunkowego dochodu podstawowego i gwarantowanego zatrudnienia." Praktyka Teoretyczna 2(24): 39-67.

DOI: $10.14746 /$ prt.2017.2.2 
AUTHOR: Mariusz Baranowski, Bartosz Mika

TITLE: Multi-Criteria Evaluation of Unconditional Basic Income and Employment Guarantee Programmes

ABSTRACT: The main aim of this article is to compare two widely discussed proposals for the reform of the developed welfare state: Unconditional Basic Income and the Job Guarantee. These proposals will be reviewed by taking into account the costs and the financing conditions, the impact on the existing the social security network, the impact on income inequality, the emancipation effect and the political possibilities of implementation. The conclusions highlighted in the summary focus on the differing needs of the core and peripheral countries, and suggest that a small empirical experience of the UBI, its potentially unfavorable macroeconomic impact, and the uncertain emancipation points towards the more convincing proposition of a job guarantee.

KEYWORDS: welfare state, full employment, poverty, social exclusion, cash transfer. 